\title{
ANALISIS IMPLEMENTASI PROGRAM KELUARGA BERENCANA DI KECAMATAN PERCUT SEI TUAN
}

\author{
Liarosa Veronika Sinaga ${ }^{1}$, Henny Arwina Bangun², Rahayu Agustina Pasaribu ${ }^{3}$ \\ Program Studi Kesehatan Masyarakat, Fakultas Farmasi dan Ilmu Kesehatan Universitas \\ Sari Mutiara Indonesia, Jl Kapten Muslim No 79, Medan 20123, Indonesia
}

*Penulis Korespondensi: Lia Rosa Veronika Sinaga, Program Studi Kesehatan Masyarakat, Fakultas Farmasi dan Ilmu Kesehatan Universitas Sari Mutiara Indonesia, Jl Kapten Muslim No 79, Medan 20123, e-mail: liarosav@yahoo.com, Phone: 085331234128

\begin{abstract}
ABSTRAK
Meningkatnya pertumbuhan penduduk di Indonesia merupakan masalah besar yang dihadapi pemerintah. Selain itu, melemahnya program Keluarga Berencana tidak cukup mampu dalam mengatasi masalah pertumbuhan penduduk di Indonesia, sehingga program keluarga berencana ditetapkan oleh pemerintah yang tujuannya yaitu untuk membentuk keluarga yang sehat dan sejahtera. Tujuan penelitian ini adalah untuk mengetahui bagaimana implementasi program keluarga berencana di Percut Sei Tuan. Penelitian ini menggunakan metode penelitian kualitatif dengan menggunakan pendekatan studi kasus. Penentuan informan dengan menggunakan teknik Purposive Sampling artinya peneliti memilih informan yang dianggap tahu (key informan) dalam penelitian ini. Teknik pengumpulan data yang digunakan adalah wawancara mendalam, observasi dan dokumentasi. Berdasarkan teori Grindle yang terdiri dari beberapa unsur yaitu kepentingan kelompok sasaran untuk bertujuan membentuk keluarga yang sehat dan sejahtera, awalnya pasangan usia subur tidak mengetahui keluarga berencana, tetapi petugas kesehatan melakukan sosialisasi. unsur kedua jenis manfaat yang memberi alat kontrasepsi seperti pil KB, KB suntik, IUD dan Implan serta memberitahu manfaat dari alat kontrasepsi yang akan digunakan. Unsur ketiga derajat perubahan yang ingin dicapai untuk meningkatkan derajat kesehatan ibu dan anak. Unsur keempat letak pengambilan keputusan, landasan dibuatnya program ini karena masih kurangnya pengetahuan tentang keluarga berencana serta masih minim informasi tentang program keluarga berencana di Percut. Unsur kelima pelaksana program yang dilakukan sekali sebulan ditempat yang sudah ditetapkan. Unsur keenam sumber daya, petugas kesehatan sudah memiliki kemampuan dalam tugas masing - masing tetapi pasangan usia subur masih ada yang tidak mau ikut program keluarga berencana. Untuk membentuk keluarga yang sehat dan sejahtera perlu melakukan pembinaan kepada sasaran supaya tingkat pengetahuan tentang keluarga berencana semakin membaik, dan harusnya dilakukan sosialisasi setiap bulan agar petugas kesehatan dan masyarakat semakin dekat.
\end{abstract}

\section{Kata Kunci : Kebijakan Program Keluarga Berencana, Teori Grindle}

\begin{abstract}
Increasing population growth in Indonesia is a major problem facing the government. In addition, the weakening of the family planning program is not sufficient to solve the problem of population growth in Indonesia, so that the family planning program is established by the government whose goal is to form a healthy and prosperous family. The purpose of this study was to determine how the implementation of the family planning program in Percut Sei Tuan. This study uses a qualitative research method using a case study approach. Determination of informants using purposive sampling technique means that researchers select informants who are considered to know (key informants) in this study. The data collection techniques used were in-depth interviews, observation and documentation. Based on the Grindle theory which consists of several elements, including the interests of the target group, the types of benefits that can be obtained, the degree of change to be achieved, the location of decision making, program implementers, and resources that the implementation of the family planning program in Percut Sei Tuan has not fulfilled the six variables in this theory, such as
\end{abstract}


there are still couples of childbearing age who do not want to participate in the implementation of the family planning program because they still believe that many children have a lot of sustenance, and are still afraid of disabilities when participating in the family planning program.

\section{Keywords : Policy Implementation, Percut, Fertile Age Couples}

\section{PENDAHULUAN}

Pertumbuhan penduduk saat ini semakin meningkat menjadi masalah besar di Indonesia dibandingkan negara lain, pertumbuhan penduduk akan mempengaruhi berbagai aspek kehidupan baik ekonomi maupun sosial, terutama peningkatan mutu kehidupan atau kualitas penduduk dalam sumber daya manusia yang dibarengi besarnya jumlah penduduk yang tidak terkontrol.

Jumlah penduduk Provinsi Sumatera Utara berdasarkan hasil sensus 2012 tercatat 13.215.401 jiwa, hingga pada tahun 2016 jumlah penduduk mencapai 14.102.911. Dengan demikian, dalam kurun waktu tersebut mengalami peningkatam sebesar 887.510 jiwa. Begitu juga di Deli Serdang berdasarkan hasil Sensus Penduduk (SP) 2010-2015 adalah 1.790.431 jiwa menjadi 2.029.308 jiwa, dengan laju pertumbuhan penduduk sebesar 2,08 persen per tahun dan kepadatan penduduk sebesar 812 jiwa per km2. Bila dilihat per kecamatan di Deli Serdang, maka Kecamatan Percut Sei Tuan merupakan kecamatan dengan jumlah penduduk terbesar dengan tingkat persebaran penduduk sebesar 21,49. (B. pusat Statistik, 2017)

Melihat kondisi tersebut, maka BKKBN menetapkan Kecamatan Percut Sei Tuan sebagai Salah satu perwujudan kampung KB tepatnya di desa Percut dan diteruskan oleh Bupati. Desa Percut terpilih dalam kategori yang tepat sebagai daerah yang menjadi contoh dalam pelaksanaan Kampung KB dikarenakan Desa Percut merupakan wilayah yang penduduknya tergolong Pra sejahtera 1, wilayah pinggiran dengan tingkat pendidikan yang rendah, serta penduduknya memiliki banyak anak. Selain itu, partisipasi masyarakat dalam ber-KB yang rendah karena minimnya pengetahun akan pentingnya ber-KB.

Menurut teori Grindle bahwa berhasilnya suatu program ditentukan oleh beberapa unsur, diantaranya ialah kepentingan kelompok sasaran untuk membentuk keluarga yang sehat dan sejahtera, jenis manfaat yang bisa diperoleh setelah melaksanakan program ini, derajat perubahan yang ingin dicapai untuk mengatur jarak kehamilan, letak pengambilan keputusan dilakukan karena masih minim tingkat pengetahuan masyarakat, pelaksana program, dan sumber daya yang digunakan. Dari penelitian terdahulu oleh Pujiyono yang membuktikan bahwa ada hubungan peran petugas kesehatan atau sumber daya merupakan salah satu indikator penentu keberhasilan suatu program menurut teori Grindle. 
Berdasarkan pemaparan diatas, maka dari itu saya tertarik untuk meneliti lebih dalam lagi tentang bagaimana penerapan kampung KB di daerah Desa Percut Deli Serdang dengan judul “ Analisis Implementasi ProgramKeluarga Berencana di Kecamatan Percut Sei Tuan Kabupaten Deli Serdang “

\section{METODE}

Jenis penelitian yang digunakan adalah penelitian kualitatif, dengan metode pendekatan studi kasus, dengan memusatkan perhatian pada implementasi kebijakan Program Keluarga Berencana dengan menggunakan Teori Grindledi Kecamatan Percut Sei Tuan. Penelitian ini dilakukan Dusun 16, 17, dan 18 di Desa Percut Kecamatan Percut Sei Tuan Kabupaten Deli Serdang Sumatera Utara. Salah satu desa yang menerapkan program kampung KB adalah

\section{HASIL}

\section{Peran Kepentingan Kelompok Sasaran dalam Implementasi Program Keluarga Berencana}

“tidak ada kepentingan lain”(Q1)

"kepentingan lain tidak ada, inikan programnya pemerintah, maka wajib pasangan usia subur mengikuti KB ini untuk meningkatkan angka kesehatan pada ibu dan anak" (A1)

"tidak ada kepentingan lain, karena program KB ini dilaksanakan atas keputusan dari pemerintah" (B1)

"tidak ada kepentingan lain. Karena program keluarga berencana ini kan program pemerintah yang dibuat untuk membatasi angka kelahiran" (P1)

Berdasarkan informasi dari hasil wawancara dengan informan penelitian tersebut, maka dapat diketahui bahwa tidak ada kepentingan lain yang mempengaruhi pelaksanaan program keluarga berencana, karena program keluarga berencana ini dilakukan untuk membatasi angka kelahiran. Selanjutnya, dalam kepentingan kelompok sasaran program keluarga berencana memnuhi kepentingan pasangan usia subur. Hal ini dilontarkan oleh keempat informan yang disajikan dalam bentuk kutipan yaitu :

“ya, memenuhi karena program KB ini bertujuan untuk membentuk keluarga yang sehat dan sejahtera" $(Q 2)$

"ya, ini merupakan kepentingan untuk pasangan usia subur, dimanakan program ini tujuannya adalah untuk meningkatkan kesejahteraan kesehatan selain itu bisa untuk menjarangkan kehamilan, mengatur jarak kehamilan” (A2)

"ya, memenuhi karena program ini dilakukukan bertujuan untuk membentuk keluarga yang sehat dan sejahtera” (B2)

"ya, memenuhi. Karena KB itu sangat penting untuk membentuk keluarga yang sehat dan sejahtera” (P2) 
Berdasarkan Informasi yang didapat peneliti melalui wawancara kepada keempat informan mengatakan bahwa program keluarga berencana dilaksanakan untuk memenuhi kesehatan bagi pasangan usia subur tujuannya untuk membentuk keluarga yang sehat dan sejahtera. Adapun pasangan usia subur mengetahui tentang pentingnya program keluarga berencana dialksanakan. Berikut hasil wawancara dengan keempat informan yaitu :

"awalnya tidak mengetahui apa itu KB, tetapi karena fasilitator sering melakukan sosialisasi maka pasangan usia subur mau ikut ber KB" (Q3)

"awalnya mereka tidak mengetahui, tetapi karena sering dilakukan sosialisasi tentang manfaat, tujuan dari alat kontrasepsi yang akan digunakan kepada pasangan usia subur" (A3)

"dulu awalnya pasangan usia subur tidak mengetahui apa itu $K B$, tetapi karena sering dilakukan sosialisasi maka pasangan usia subur mau ikut ber KB” (B3)

"dulu masyarakat terutama pasangan usia subur tidak mau tahu tentang $K B$, tetapi karena sering dilakukan sosialisasi maka mereka mau ikut untuk ber KB” (P3)

Berdasarkan Informasi yang didapat dari Ibu kepala desa sama halnya dengan Ibu pegawai kecamatan selaku pengawas program dan Ibu Kepala bidang KB selaku penanggung jawab program mengatakan bahwa pasangan usia subur awalnya tidak mengetahui apa itu keluarga berencana, tetapi karena sering dilakukan penyuluhan maka mereka mau mengikuti program keluarga berencana.

\section{Peran Jenis Manfaat dalam Implementasi Program Keluarga Berencana}

"program keluarga berencana ini ditetapkan oleh pemerintah dan sudah dilaksanakan di Percut Sei Tuan, masyarakat pasangan usia subur sudah mengikuti program ini sehingga kesehatan ibu dan anak sudah meningkat” (Q1)

"dalam pelaksanaan program KB awalnya diberikan penyuluhan kepada masyarakat terutama pasangan usia subur maka setelah diberikan sosialisasi mereka mengikuti program ini sehingga kesehatan ibu dan anak sudah membaik” (A1)

"awalnya pelaksanaan program KB dilakukan dengan cara sosialisasi kepada masyarakat, sehingga pasangan usia subur mengikuti program ini maka dengan dilaksanakan program KB kesehatan ibu dan anak meningkat" (B1)

"program ini ditetapkan oleh pemerintah, maka sudah dilaksanakan di Percut Sei Tuan.

Untuk melaksanakan program ini diberikan sosialisasi supaya masyarakat mengetahui apa itu keluarga berencana dengan proses yang sudah dilakukan maka kesehatan ibu dan anak sudah meningkat" (P1)

Berdasarkan wawancara yang diperoleh dari pengawas maupun penanggung jawab program mengatakan hal yang sama bahwa pelaksanaan dari program keluarga berencana sudah ditetapkan oleh pemerintah dan pasangan usia subur sudah mengikuti program ini 
sehingga kesehatan ibu dan anak sudah meningkat. Selanjutnya peningkatan yang diperoleh setelah melaksanakan program keluarga berencana. Berikut hasil wawancara yang didapat dari keempat informan yaitu :

"peningkatan yang didapat ada, tapi sebelumnya tidak gampang untuk mengajak masyarakat untuk mengikuti program ini” (Q2)

"peningkatannya kesehatan ibu dan anak sudah membaik” (A2)

"ada peningkatan yang sudah membaik” (B2)

"peningkatan sudah ada tapi masyarakat terutama pasangan usia subur masih ada sebagian yang belum mengikuti program keluarga berencana ini” (P2)

Informasi yang diperoleh dari pengawas maupun penanggung jawab program mengatakan hal yang sama bahwa sudah ada peningkatan kesehatan Ibu dan anak setelah dialksanakan program keluarga berencana.

\section{Peran Derajat Perubahan dalam Implementasi Program Keluarga Berencana}

"harapannya adalah untuk meningkatkan angka kesehatan ibu dan anak, serta membentuk keluarga yang sehat dan sejahtera” (Q1)

"harapannya terutama pada pasangan usia subur untuk meningkatkan kesehatan ibu dan anak, menekan angka kelahiran yang banyak, mengatur jarak kehamilan” (A1)

"harapannya untuk membentuk keluarga yang sehat dan sejahtera dengan cara mengatur jarak kehamilan” (B1)

"meningkatkan angka kesehatan dan membentuk keluarga yang sehat dan sejahtera serta mengatur jarak kehamilan” (P1)

Berdasarkan informasi dari hasil wawancara dari keempat informan mengatakan bahwa derajat perubahan membaik dengan adanya program tersebut, maka yang diharapkan dengan adanya program keluarga berencana yaitu untuk membentuk keluarga yang sehat dan sejahtera, dan mengatur jarak kehamilan. Selain itu, angka kematian ibu dan anak berkurang dengan adanya program keluarga berencana dilaksanakan. Berikut hasil kutipan dari keempat infoman yaitu :

“ya, angka kematian ibu dan anak berkurang” (Q2)

"ya, berdasarkan data yang kami dapat sudah berkurang angka kematian ibu dan anak" (A2)

“ya, sudah berkurang” (B2)

“dari data yang kami kumpul angka kematian ibu dan anak berkurang” (P2)

Pada hasil wawancara yang diperoleh dari pengawas program dan penanggung jawab program mengatakan bahwa angka kematian ibu dan anak berkurang dengan adanya program keluarga berencana. Maka, derajat kesehatan semakin meningkat di Percut Sei Tuan setelah 
dilaksanakan program keluarga berencana. Berikut hasil wawancara dengan keempat informan

"ya, setelah program KB di laksanakan derajat kesehatan terutama ibu dan anak meningkat" (Q3)

"ya setelah kita melakukan sosialisasi dan PUS juga mengikuti program ini, derajat kesehatan semakin meningkat” (A3)

“ya, meningkat” (B3)

"ya setelah kita melakukan sosialisasi dan PUS juga mengikuti program ini, derajat kesehatan semakin meningkat” (P3)

Informasi yang diperoleh dari pengawas maupun penanggung jawab program mengatakan hal yang sama bahwa derajat kesehatan semakin meningkat dengan adanya program keluarga berencana dilaksanakan.

\section{Peran Letak Pengambilan Keputusan dalam Implementasi Program Keluarga Berencana}

"landasannya karena masyarakat terutama pasangan usia subur di Percut masih kurang pengetahuan tentang $K B$ " (Q1)

"landasannya ya kita mengingat ini adalah programnya pemerintah, tanggung jawab kita adalah memberi sosialisasi dan memfasilitasi masyarakat untuk mengikuti program $K B$, apalagi mengingat di desa kita ini masih sangat minim informasi tentang program $K B$ " (A1)

"landasannya karena masyarakat terutama pasangan usia subur masih kurang pengetahuan tentang informasi program keluarga berencana” (B1)

"landasannya karena masyarakat terutama pasangan usia subur masih kurang pengetahuan tentang informasi program keluarga berencana” (P1)

Pada hasil wawancara yang diperoleh dari pengawas maupun penanggung jawab program mengatakan hal yang sama bahwa landasan dibuatnya program keluarga berencana yaitu karena masyarakat masih kurang pengetahuan tentang keluarga berencana. Selanjutnya, mengetahui keputusan apa yang harus diambil dalam pelaksanaan program keluarga berencana. Berikut hasil kutipan dari informan yaitu :

"sebagai fasilitator mengajak pasangan usia subur untuk mengikuti keluarga berencana" (Q2)

"mengajak pasangan usia subur untuk bersepakat menjalankan program keluarga berencana ini” (A2)

"mengajak pasangan usia subur untuk mengikuti program ini" (B2)

“mengajak pasangan usia subur untuk ikut ber KB” (P2)

Pada hasil wawancara yang diperoleh dari pengawas maupun penanggung jawab program mengatakan hal yang sama bahwa keputusan yang harus diambil dalam pelaksanaan program keluarga berencana yaitu mengajak pasangan usia subur untuk mengikuti program, 
mengajak suami istri untuk bersepakat menjalankan program tersebut.

\section{Peran Pelaksana Program dalam Implementasi Program Keluarga Berencana}

“ya fasilitator ada melakukan sosialisasi sebelum pelaksanaan program dilakukan” (Q1)

"ya kita melakukan sosialisasi kepada masyarakat mengenai manfaat dari keluarga berencana ini" (A1)

"ada diberikan sosialisasi mengenai manfaat dari keluarga berencana” (B1)

"ya, kita melakukan sosialisasi kepada pasangan usia subur mengenai manfaat dari keluarga berencana" (P1)

Pada hasil wawancara yang diperoleh dari pengawas maupun penanggung jawab program mengatakan hal yang sama bahwa ada diberikan sosialisasi kepada pasangan usia subur mengenai manfaat dari keluarga berencana. Selanjutnya pelaksana memberikan pemahaman tentang program keluarga berencana dengan melakukan sosialisasi. Berikut kutipan yang disampaikan informan yaitu :

"sosialisasi dilaksanakan dibalai desa, sosialisasi dilakukan dengan memberitahu manfaat dari program KB dilaksanakan dan memberitahu manfaat serta tujuan dari alat kontrasepsi yang akan diberikan kepada sasaran” (Q2)

"sosialisasi dilakukan untuk memberitahu manfaat tentang KB serta memberitahu manfaat atau kegunaan dari alat kontrasepsi yang akan dipakai” (A2)

"memberitahu pemahaman tentang manfaat $K B$ dan memberitahu manfaat dari alata kontrasepsi” (B2)

"mengajak masyarakat untuk berkumpul dibalai desa, maka disana dilakukan sosialisasi tentang manfaat KB serta memberitahu manfaat dari alat kontrasepsi yang akan dipakai pasangan usia subur" (P2)

Informasi yang diperoleh dari pengawas maupun penanggung jawab program mengatakan hal yang sama bahwa sosialisasi dilaksanakan dibalai desa, sosialisasi dilakukan untuk memberitahu manfaat dari program keluarga berencana dan memberitahu manfaat serta tujuan dari alat kontrasepsi yang akan diberikan kepada pasangan usia subur. Maka, pelayanan KB saat dilakukan program keluarga berencana. Berikut hasil wawancara yang dilakukan dengan informan yaitu :

"pelayana KB sudah mengetahui setiap tugasnya dan sudah mengetahui manfaat dan tujuan dari alat kontrasepsi yang akan diberikan kepada sasaran” (Q3)

“petugas KB sudah mengetahui manfaat atau kegunaan dari alat kontrasepsi” (A3) "pelayanan KB sudah mengerti dari alat kontrasepsi yang akan diberikan kepada sasaran” (B3)

"pelayanan KB sudah mengetahui dari alat kontrasepsi yang akan diberikan kepada pasangan usia subur" (P3)

Informasi yang diperoleh dari pengawas maupun penanggung jawab program 
mengatakan hal yang sama bahwa pelayanan KB sudah mengetahui dari alat kontrasepsi yang akan diberikan kepada pasangan usia subur.

\section{Peran Sumber daya dalam Implementasi Program Keluarga Berencana}

"saya lihat, petugas pelayanan kesehatan sudah memiliki kemampuan masing-masing saat pelaksanaan program keluarga berencana dilakukan” (Q1)

"setiap petugas sudah memiliki kemampuan dan memahami setiap tugas masingmasing saat pelaksanaan program KB tersebut" (A1)

“ya, sudah memiki kemampuan dalam pelaksanaan program KB” (B1)

“petugas kesehatan sudah mengerti dan mampu tentang program KB” (P1)

Pada hasil wawancara yang diperoleh dari pengawas program dan penanggung jawab program mengatakan bahwa sumber daya manusia dalam program keluarga berencana ini sudah memiliki kemampuan dan keterampilan dalam melaksanakan program ini. Selanjutnya, adapun peran setiap sumber daya manusia dalam melakukan kegiatan program keluarga berencana dilapangan. Berikut hasil kutipan dari informan yaitu :

"setiap petugas sudah memiliki tugas masing-masing saat pelaksanaan program KB" (Q2)

"setiap petugas sudah memiliki tugas masing-masing sesuai kemampuan mereka disaat pelaksanaan program KB dilakukan” (A2)

“petugas sudah memiliki kemampuan sesuai dengan bidang mereka saat program KB dilakukan" (B2)

"setiap petugas sudah memiliki tugas masing-masing sesuai dengan pengetahuan atau kemampuan tentang program KB” (P2)

Berdasarkan hasil wawancara terkait peran setip sumber daya manusia dalam melakukan kegiatan program keluarga berencana, keempat informan mengatakan bahwa petugas sudah memiliki tugas masing - masing sesuai dengan pengetahuan dan kemampuan dalam pelaksanaan program ini. Maka sumber daya manusia sudah semua terlibat dalam pelaksanaan program keluarga berencana. Berikut hasil wawancara dengan keempat informan yaitu :

"petugas dalam pelaksanaan program keluarga berencana ini sudah semua terlibat dan memiliki tugas masing-masing” (Q3)

“kalau untukfasilitator sudah semua terlibat dan memiliki tugas masing-masing” (A3)

“fasilitator sudah semua terlibat” (B3)

"petugas dalam pelaksanaan program keluarga berencana ini sudah semua terlibat dan memiliki tugas masing-masing” (P3)

Berdasarkan hasil wawancara terkait dalam pelaksanaan program, petugas sudah terlibat dalam melakukan program ini, pengawas dan penanggung jawab program mengatakan 
hal yang sama bahwa petugas sudah terlibat dalam pelaksanaan program keluarga berencana. Adapun dana dari pemerintah untuk menjalankan program keluarga berencana. Berikut hasil kutipan dari keempat informan yaitu :

“ada” (Q4)

“ada, karena ini program dari pemerintah” (A4)

“ada” (B4)

“dana ada dari pemerintah" (P4)

Berdasarkan hasil wawancara terkait dana dalam melakukan program keluarga berencana. pengawas dan penanggung jawab program mengatakan hal yang sama bahwa dana ada dari pemerintah saat melaksanakan program. Selanjutnya, adapun setiap infoman mengalokasikan anggaran untuk pelaksanaan program keluarga berencana. Berikut hasil wawancara dari keempat informan yaitu :

“tidak ada" (Q5)
"tidak ada" (A5)
“tidak ada" (B5)
"tidak ada" (P5)

Berdasarkan hasil wawancara terkait dana dalam melakukan program keluarga berencana. pengawas dan penanggung jawab program mengatakan hal yang sama bahwa mereka tidak ada mengalokasikan anggaran saat pelaksanaan program dilakukan.

\section{PEMBAHASAN}

\section{Kepentingan Kelompok Sasaran dalam Implementasi Program Keluarga Berencana}

Dari hasil penelitian menunjukkan bahwa informan seperti pengawas program keluarga berencana dan pelaksana program mengatakan bahwa tidak ada kepentingan lain selain untuk membentuk keluarga yang sehat dan sejahtera. Di laksanakan program keluarga berencana ini untuk meningkatkan derajat kesehatan Ibu dan anak. Awalnya pasangan usia subur tidak mengetahui tentang keluarga berencana tetapi petugas kesehatan sebagai fasilitator melakukan sosialisasi manfaat, tujuan dari alat kontrasepsi yang akan digunakan pasangan usia subur. Lokasi dalam melaksankan program keluarga berencana sudah ditetapkan menjadi tempat ditiap dusun.

Menurut penelitian yang dilakukan oleh (Lopang, 2019) bahwa kepentingankepentingan yang mempengaruhi pelaksanaan program keluarga berencana yaitu terdiri dari program kependudukan, program keluarga berencana dan kesehatan reproduksi dan program pembangunan keluarga. Kepentingan yang mempengaruhi pelaksanaan program keluarga berencana terdapat pada kepentingan BKKBN untuk meningkatkan program KB-KR, program 
PK dan program kependudukan

\section{Jenis Manfaat dalam Implementasi Program Keluarga Berencana}

Dari penelitian yang sudah dilakukan memaparkan bahwa pelaksanaan program keluarga berencana dilakukan dengan cara sosialisasi kepada masyarakat terutama pasangan usia subur maka setelah setelah diberikan sosialisasi masyarakat mengikuti program ini sehingga kesehatan ibu dan anak semakin meningkat. Petugas kesehatan juga sudah mengetahui manfaat dan tujuan dari alat kontrasepsi yang akan diberikan kepada pasangan usia subur.

Hasil penelitian yang dilakukan oleh (Lopang, 2019) bahwa yang diharapkan yaitu untuk dapat meningkatkan kualitas hidup masyarakat di tingkat kampung atau yang setara melalui program kependudukan, keluarga berencana dan pembangunan keluarga serta pembangunan sektor terkait dalam rangka mewujudkan keluarga kecil yang berkualitas dengan memberikan wawasan pengetahuan kepada masyarakat pasangan usia subur dengan cara penyuluhan. Manfaat positif dengan mengikuti pembinaan dari DP3AKB, namun manfaat tersebut tidak disalurkan kembali kepada masyarakat. dampaknya partisipasi masyarakat menjadi rendah. Adapula manfaat yang dirasakan yaitu meningkatnya jumlah akseptor KB di Kampung Kaliwadas, masyarakat dapat merasakan manfaat adanya program KB yaitu dari pelayanan $\mathrm{KB}$ gratis

\section{Derajat Perubahan dalam Implementasi Program Keluarga Berencana}

Dari hasil penelitian yang sudah dilakukan memaparkan bahwa derajat perubahan yang ingin dicapai yaitu untuk meningkatkan derajat kesehatan Ibu dan anak, menekan angka kelahiran yang banyak dalam arti mengatur jarak kehamilan dari anak yang satu ke anak yang lain serta membentuk keluarga yang sehat dan sejahtera.

Menurut penelitian yang dilakukan oleh (Utara \& Utara, 2018) pelaksanaan kebijakan pasti memiliki suatu target atau ukuran perubahan yang ingin dicapai, seperti perubahan yang diinginkan ataupun perubahan yang sudah dihasilkan dari pelaksanaan suatu kebijakan. Dalam pelaksanaan program kampung KB ini, terdapat suatu derajat perubahan yang ingin dicapai, perubahan tersebut secara umum terdapat pada tujuan dari program KB yaitu untuk meningkatkan kualitas hidup masyarakat melalui program KKBPK dan juga pembangunan di sektor terkait untuk mewujudkan keluarga kecil yang berkualitas. Derajat perubahan yang ingin dicapai pada pelaksanaan program KB di Kaliwadas belum sesuai dengan indikator keberhasilan salah satunya perubahan yang diinginkan para pihak pelaksana KB yang terdapat pada tujuan KB dan juga 8 fungsi keluarga, adanya beberapa hambatan seperti pengurus KB yang kurang mengetahui dan memahami 8 fungsi keluarga juga acara atau kegiatan yang 
dilaksanakan di program KB yang belum tepat sasaran, sehingga dapat menyebabkan perubahan yang diharapkan kurang maksimal

\section{Letak Pengambilan Keputusan dalam Implementasi Program Keluarga Berencana}

Letak pengambilan keputusan terhadap pelaksanaan program dilihat dari lokasinya terlebih dahulu. dari hasil penelitian yang sudah dilakukan memaparkan bahwa landasan dibuatnya program keluarga berencana di Percut Sei Tuan yaitu mengingat ini adalah programnya pemerintah, tanggung jawab kita adalah memberi sosialisasi dan memfasilitasi masyarakat untuk mengikuti program KB, apalagi mengingat masyarakat Percut masih sangat minim informasi tentang program keluarga berencana.

Hasil penelitian yang dilakukan oleh (Ali et al., 2019) Pada suatu kebijakan adanya letak pengambilan keputusan merupakan hal yang sangat penting. Hal ini dikarenakan suatu kebijakan akan jelas di implementasikan jika letak pengambilan keputusan sudah diketahui, letak pengambilan keputusan dalam implementasi program keluarga berencana yaitu berada di pihak BKKBN dan DP3AKB. Selain itu, dukungan dari lintas sektor terhadap program KB di kampung Kaliwadas juga berperan penting dalam pengambilan keputusan di kampung KB, namun lintas sektor ini belum berjalan dengan maksimal, karena belum banyak lintas sektor yang bekerjasama dengan KB Kaliwadas, dan yang sudahpernah bekerjasama pun belum terdapat dampak yang terlihat jelas, sehingga belum maksimal.

\section{Pelaksana Program dalam Implementasi Program Keluarga Berencana}

Pelaksana Program sangat berkaitan dengan berhasil tidaknya suatu program dapat dijalankan dengan baik. Dari hasil penelitian memaparkan bahwa pelaksana program maupun pengawas pelaksana program keluarga berencana ini dengan bentuk dukungan berupa memahami tugasnya masing-masing. Fasilitaor juga melakukan sosialisasi kepada masyarakat terutama pasangan usia subur dan petugas kesehatan sebagai pelayanan KB sudah mengetahui manfaat dari alat kontrasepsi yang akan diberikan kepada sasaran, pasangan usia subur juga mendapatkan pelayanan yang baik.

Dari hasil penelitian yang dilakukan oleh (Lopang, 2019) Indikator pelaksanaan program dalam suatu pelaksanaan kebijakan atau program sangatlah berpengaruh terhadap keberhasilan atau kegagalan pada saat program tersebut diimplementasikan. Dalam pengimplementasian program keluarga berencana ini terdapat pelaksana program yang mendukung jalannya program tersebut yaitu BKKBN, DP3AKB, dan Pos Penyuluhan KB. Pelaksana program KB yang pertama yaitu BKKBN yang menjelaskan bahwa mereka rutin pertanggal 20 mengadakan rapat pengendalian program, jadi dalam rapat pengendalian program tersebut adalah media evaluasi dan penyusunan rencana kegiatan, hal tersebut sudah 
melakukan pengawasan terlebih dalahu program keluarga berencana. Pelaksana program dalam implementasi program keluarga berencana di Kampung Kaliwadas sebenarnya hanya terdapat 2 pihak pelaksana program yaitu BKKBN dan DP3AKB. Namun terdapat pelaksana program lain yang berperan penting karna yang mengkoordinasikan antara pihak BKKBN dan DP3AKB kepada pengurus program keluarga berencana.

\section{Sumber Daya dalam Implementasi Program Keluarga Berencana}

Dari penelitian yang sudah dilakukan memaparkan bahwa sumber daya dalam melaksanakan program keluarga berencana ini sudah memadai serta telah memiliki kemampuan yang cukup untuk menjalankan program ini, dan petugas telah mengetahui tugas masing-masing. Karena program keluarga berencana ini adalah program dari pemerintah maka dana dialokasikan oleh pemerintah.

Hasil penelitian yang dilakukan oleh (Lopang, 2019) Kebijakan atau program akan berhasil diimplementasikan jika menggunakan dan didukung dengan sumberdaya yang baik. Adapun dalam implementasi program keluarga berencana ini menggunakan sumberdaya yang mencakup mengenai sumberdaya manusia dan sumberdaya financial yang digunakan dalam pelaksanaan program kampung KB tersebut. Sumberdaya yang digunakan yaitu: Pertama, sarana dan prasarana yang ada dalam menunjang program KB. Sarana dan prasarana yang paling dibutuhkan yaitu rumah data dan kesekretariatan KKB, jadi ada tempat untuk melakukan kegiatan keluarga berencana. Sarana yang seharuasnya ada di kampung KB yaitu seperti untuk $\mathrm{BKB}$ ada buku materi tentang $\mathrm{BKB}$, materi kesehatan reproduksi, dan juga sarana lainnya seperti BKB Kit dan lain-lain, itu merupakan sarana utama yang seharusnya terdapat di BKB.

\section{KESIMPULAN}

1. Kepentingan kelompok sasaran masih belum maksimal karena saat melakukan sosialisasi tidak ada diberi tahu media cetak, sehingga yang mendapatkan informasi hanya masyarakat yang pernah mengikuti program keluarga berencana.

2. Dari segi jenis manfaat sudah ada peningkatan kesehatan ibu dan anak tetapi masih ada sebagian pasangan usia subur yang tidak mengikuti program keluarga berencana ini.

3. Derajat perubahan sudah semakin membaik namun belum sesuai harapan.

4. Letak pengambilan keputusan sudah sesuai dengan lokasi namun masih ada yang tidak mau ikut ber $\mathrm{KB}$

5. Dari segi pelaksana program sudah baik, terlihat pada implementor yang sudah mendukung program ini

6. Sumber daya manusia sudah mencukupi dan sudah mengerti tugas masing-masing yang 
memiliki kemampuan dan tanggung jawab saat pelaksanan program dilakukan.

\section{REFERENSI}

1. Abstraksi. (1984). Perspektif, Model Dan Kriteria Pengukurannya IMPLEMENTASI KEBIJAKAN :, 65-85.

2. Ali, M., Junaidi, M., \& Hafiz, A. (2019). Implementasi Program Desa Keluarga Berencana Bagi Kesejahteraan Masyarakat Studi Kasus Geguntur Mataram, 23(2), 9599.

3. BKKBN. (2015). RENSTRA_Biren_Tahun_2015_2019.Pdf.

4. Depkes, D. K. R. (2008). Profil Kesehatan.

5. Hambar, W. (2020). Implementasi Program Keluarga Berencana Di Puskesmas Kecamatan Kualuh Hilir Kabupaten Labuhanbatu Utara Tahun 2019.

6. Hardhana, B., Budiono, C. S., Kurniasih, N., Manullang, E. V, Susanti, M. I., Pangribowo, S., ... Sigit, B. B. (2016). Data Dan Informasi Kesehatan.

7. Hukum, S., Program, I., Syariah, J., Ekonomi, D., Program, I., Ahwal, S., ... Negeri, I. (2016). Oleh : Aji Wibowo NIM : 210112047 Pembimbing Layyin Mahfiana Sh ., M . Hum Jurusan Syariah Dan Ekonomi Islam Sekolah Tinggi Agama Islam Negeri ( STAIN ) Ponorogo, 94-117.

8. Indonesia, Presiden Republik. (2014). Peraturan Pemerintah Republik Indonesia Nomor 87 Tahun 2014.

9. Kemenkes, Pusat Data. (2013). Infodatin-Kb.Pdf.

10. Kependudukan, B., Keluarga, D. A. N., \& Nasional, B. (2015). Rencana Strategis Badan Kependudukan Dan KB Nasional.

11. Lopang, K. K. (2019). Fakultas Ilmu Sosial Dan Ilmu Politik Universitas Sultan Ageng Tirtayasa Serang 2019.

12. Permatasari, P. (2016). Analisis Implementasi Peraturan Daerah Kota Semarang Nomor 3 Tahun 2013 Tentang Kawasan Tanpa Rokok Di Kota Semarang ( Studi Kasus Di Universitas Dian Nuswantoro Semarang ).

13. Pustaka, A. T. Keluarga Berencana, \& Berencana, K. (2010). Keluarga Berencana.

14. Saryono, \& Anggraeni, M. D. (2011). Metodologi Penelitian Kualitatif Dalam Bidang Kesehatan. Yogyakarta: Nuha Medika.

15. Selatan, K., \& Kotamobagu, K. (2018). Issn : 2337 - 5736, (1).

16. Statistik, Badan Pusat. (2015). Profil Penduduk Indonesia Hasil Supas.

17. Statistik, B. Pusat. (2017). Badan Pusat Statistik.

18. Utami, Mustika Purnama. (2018). Skripsi Mustika Purnama Utami.

19. Utara, U. S., \& Utara, U. S. (2018). Implementasi Program Kampung Keluarga Berencana Di Desa Percut Kecematan Percut Sei Tuan Kabupaten Deli Serdang. 